\title{
PENINGKATAN KEMAMPUAN PENGUCAPAN BAHASA INGGRIS BAGI GURU PENDIDIKAN ANAK USIA DINI (PAUD) DI KECAMATAN ASEMBAGUS KABUPATEN SITUBONDO
}

\author{
Firqo Amelia ${ }^{1}$, Sufil Lailiyah ${ }^{2}$ \\ ${ }^{1,2}$ Program Studi Sastra Inggris, Fakultas Sastra \\ Universitas Abdurachman Saleh Situbondo \\ Email: firqo.amelia@gmail.com
}

\begin{abstract}
This activity resolved one of the problems faced by Early Childhood Education (PAUD) teachers in Asembagus, the inability of PAUD teachers to pronounce English vocabulary taught to their students. For this reason, the English for Young Learners training focused primarily on checking and improving English pronunciation of PAUD teachers was held. This program lasted one month with three stages: preparation, training and evaluation. The purpose of the preparation stage was to establish communication with the partner, RA Munawarus Sholeh Mojosari, Asembagus. Second, the training stage took place over four days comprised of basic English vocabulary, EYL (English for Young Learners) learning media, learning methods, pronunciation, and technology utilization. The last was the evaluation stage where the organizers measured and reflected on the success of the project. Outputs generated from this activity were: (1) Increasing basic English vocabulary of PAUD teachers that was usually taught to the students; (2) Proper pronunciation of some basic English vocabulary of PAUD teachers; (3) Improved PAUD teacher skills in teaching English to early childhood learners; (4) Improved PAUD teacher skills in using a dictionary application to check the pronunciation of English words; and (5) Increasing Motivation of PAUD teachers in developing English language skills.
\end{abstract}

Keywords: pronunciation, english, early childhood education, english for young learners

\begin{abstract}
Abstrak. Kegiatan ini menyelesaikan salah satu permasalahan yang dihadapi oleh guru Pendidikan Anak Usia Dini (PAUD) di Asembagus yaitu minimnya kemampuan guru PAUD dalam hal pelafalan kosa kata Bahasa Inggris untuk diajarkan pada anak didik mereka. Untuk itu, pelatihan pembelajaran Bahasa Inggris untuk anak usia dini (English for Young Learners) yang difokuskan terutama pada pengecekan dan perbaikan pelafalan kosa kata Bahasa Inggris yang dimiliki oleh guru PAUD dilakukan. Program ini dilaksanakan selama sebulan dengan tiga tahap, yaitu tahap persiapan, pelatihan, dan evaluasi. Tahap persiapan dilakukan untuk menjalin komunikasi dengan pihak mitra, yaitu RA. Munawarus Sholeh Mojosari, Asembagus. Kedua, tahap pelatihan yang dilakukan selama empat hari dengan pemberian materi berupa kosa kata dasar Bahasa Inggris, media pembelajaran EYL (English for Young Learners), metode pembelajaran, pelafalan (pronunciation), dan pemanfaatan teknologi. Yang terakhir yaitu evaluasi. Luaran yang dihasilkan dari kegiatan ini adalah: (1) Bertambahnya kosa kata dasar Bahasa Inggris guru PAUD yang biasa diajarkan pada anak didik; (2) Pelafalan beberapa kosa kata dasar Bahasa Inggris guru PAUD yang benar; (3) Keterampilan guru PAUD dalam mengajarkan bahasa Inggris kepada anak usia dini; (4) Keterampilan guru PAUD dalam menggunakan aplikasi kamus dalam mengecek pengucapan kata-kata Bahasa Inggris; dan (5) Motivasi guru PAUD dalam mengembangkan keterampilan bahasa Inggris yang meningkat.
\end{abstract}

Kata kunci: pelafalan, bahasa inggris, pendidikan anak usia dini, english for young learners

\section{PENDAHULUAN}

Pendidikan memiliki peranan yang sangat penting dalam membentuk manusia berkualitas dan beradab. Oleh sebab itu, pendidikan seyogyanya diperoleh seseorang sejak usia dini, begitupun dengan pendidikan tentang bahasa. Hutauruk (2015, hlm. 52) mengatakan bahwa usia sebelum lima tahun merupakan usia emas (golden age) bagi proses pemerolehan bahasa anak. Karena pada usia tersebut, anak dapat dengan mudah menangkap dan merekam apa yang dipelajarinya. Oleh karenanya, sangat penting untuk memulai pendidikan bahasa seseorang sejak usia dini.

Undang-undang No. 20 tahun 2003 pasal 1 ayat 14 menyebutkan bahwa pendidikan anak usia dini adalah suatu upaya pembinaan yang ditujukan kepada anak sejak lahir sampai dengan usia enam tahun yang dilakukan melalui rangsangan pendidikan untuk membantu pertumbuhan dan perkembangan jasmani dan rohani agar anak memiliki kesiapan dalam 
memasuki pendidikan lebih lanjut. Sepatutnya pendidikan anak usia dini ini menjadi tanggung jawab para orang tua. Namun pada prakteknya, kebanyakan orang tua tidak mampu untuk memberikan pendidikan pada putra-putrinya. Dari kenyataan ini, kebanyakan orang tua menyerahkan pendidikan usia dini anaknya kepada lembaga-lembaga pendidikan anak usia dini (PAUD). Di Indonesia, lembaga pendidikan anak usia dini (PAUD) terbagi menjadi pendidikan pra-sekolah dan Taman Kanak-Kanak (TK) formal, serta kelompok bermain (KB) nonformal dan pusat penitipan anak. KB melayani anak usia 2-6 tahun, sedangkan TK melayani anak usia 4-6 tahun (Unicef 2012, p. 3).

Pembelajaran bahasa, khususnya bahasa asing, bagi anak usia dini mempunyai perbedaan dengan pembelajaran bahasa pada umumnya. Guru, sebagai pendamping, tidak hanya dituntut untuk menguasai materi, tetapi juga dituntut untuk menguasai situasi. Selain menjadi tutor, guru juga dituntut untuk berperan sebagai partner dalam belajar.

Pembelajaran bahasa untuk anak usia dini pada umumnya dilakukan di lembaga formal Taman Kanak-Kanak (TK) atau Raudlatul Athfal (RA). Kedua lembaga tersebut merupakan dua lembaga yang mempunyai tujuan sama, namun berada pada naungan yang berbeda. Berbeda dengan TK yang berada di bawah naungan Kementrian Pendidikan dan Kebudayaan, RA, sebagai lembaga di bawah naungan Kementerian Agama, dipandang sebagai lembaga yang perlu lebih diperhatikan karena minimnya fasilitas, baik berupa media pembelajaran ataupun guru. Oleh sebab itu, program pengabdian ini ditujukan untuk guru-guru RA. Diharapkan dengan program ini, guru-guru RA dapat meningkatkan kemampuan mereka, khususnya dalam bidang bahasa Inggris.

Sebagai kota kecil, Situbondo merupakan kota yang masih membutuhkan banyak masukan dalam hal pembelajaran bahasa asing, khususnya untuk anak usia dini. Di samping karena minimnya fasilitas yang tersedia, kurangnya jumlah tenaga pengajar yang mampu mengajarkan bahasa asing, khususnya dalam mengucapkan kosa kata Bahasa Inggris dengan benar, juga menjadi masalah yang harus segera diselesaikan. Oleh karenanya, pengabdian ini dilakukan di salah satu kecamatan yang terdapat di Kabupaten Situbondo, yaitu Kecamatan Asembagus.

RA. Munawarus Sholeh merupakan lembaga formal untuk anak usia dini yang terletak di Kecamatan Asembagus. Sebagai lembaga yang melayani kebutuhan pendidikan anak usia dini, lembaga ini sangat berperan dalam membentuk kemampuan bahasa asing anak didiknya. Mengingat apa yang diajarkan oleh guru RA akan melekat dalam otak anak didik, bahkan hingga yang bersangkutan dewasa, sudah selayaknya para guru RA memiliki pengetahuan yang bagus tentang Bahasa Inggris dasar.

Namun pada kenyataannya, proses pembelajaran bahasa asing (bahasa Inggris) di RA tersebut belum berjalan lancar. Umumnya, hal ini disebabkan oleh kurangnya kemampuan (skill) para guru dalam mengucapkan kosa kata Bahasa Inggris dengan benar. Permasalahan pengajaran bahasa Inggris ini sangat perlu diselesaikan mengingat pentingnya kemampuan bahasa Inggris dimiliki oleh setiap orang dalam era globalisasi saat ini, serta pentingnya peran guru RA sebagai guru pertama bagi seorang anak. Oleh sebab itu, program pengabdian ini dilaksanakan di lembaga tersebut.

\section{Profil RA.Munawarus Sholeh Mojosari Asembagus}

RA. Munawarus Sholeh merupakan lembaga pendidikan untuk anak usia dini yang terletak di desa Mojosari Kecamatan Asembagus Kabupaten Situbondo. Sekolah ini melangsungkan proses belajar-mengajarnya pada hari Senin - Sabtu dimulai pada pukul 07.00 WIB dan berakhir pada pukul 10.00 WIB. Gambaran umum tentang RA. Munawarus Sholeh dan proses belajar-mengajarnya dapat dilihat pada gambar-gambar berikut. 


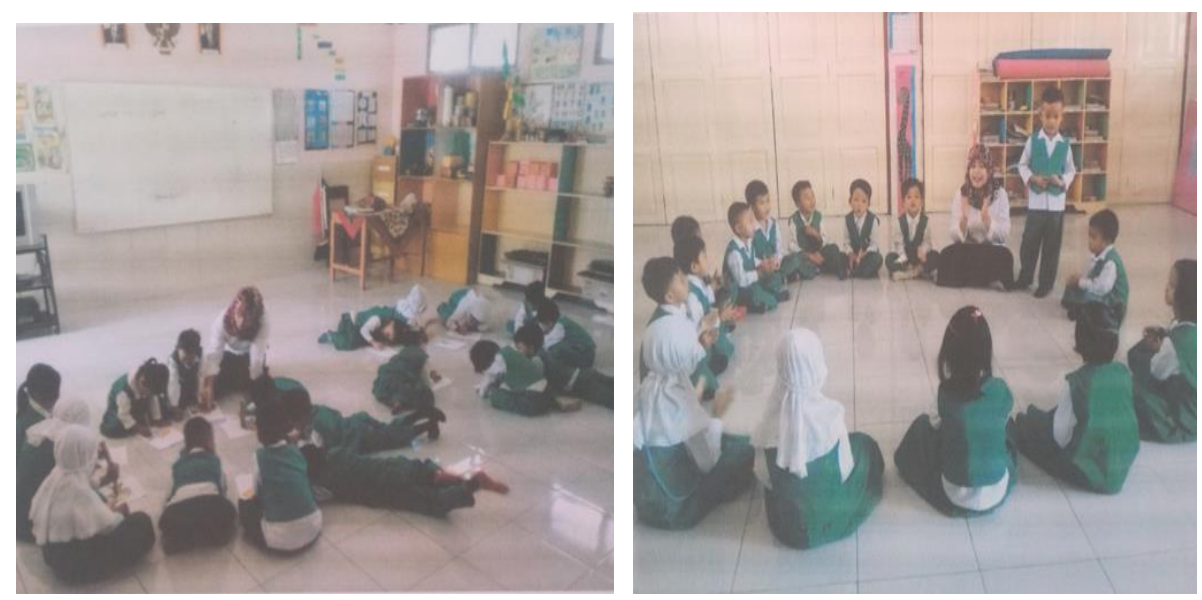

Gambar 1. Kegiatan belajar-mengajar di RA. Munawarus Sholeh

Pada tahun pelajaran 2017-2018 sekolah kelompok B. Adapun detail jumlah anak didik ini memiliki anak didik sebanyak 60 anak yang yang terdapat di RA. Munawarus Sholeh seperti terdiri atas 33 anak kelompok A dan 27 anak yang ditunjukkan oleh tabel 1 berikut.

Tabel 1. Jumlah anak didik di RA. Munawarus Sholeh pada tahun pelajaran 2017-2018

\begin{tabular}{ccccc}
\hline \multirow{2}{*}{ No. } & \multirow{2}{*}{ Kelompok } & \multicolumn{2}{c}{ Jumlah } & \multirow{2}{*}{ Total } \\
\cline { 3 - 4 } & & Pr & Lk & \\
\hline 1. & $\mathrm{~A}$ & 15 & 18 & 33 \\
\hline 2. & $\mathrm{~B}$ & 12 & 15 & 27 \\
\hline \multicolumn{2}{l}{ Total anak didik } & 27 & 33 & 60 \\
\hline
\end{tabular}

Sejumlah anak didik tersebut dibimbing terdapat di RA. Munawarus Sholeh seperti oleh para guru sejumlah enam orang. Adapun ditunjukkan oleh tabel 2 berikut. nama-nama guru serta staf administrasi yang

Tabel 2. Sumber Daya Manusia di RA. Munawarus Sholeh

\begin{tabular}{cllcc}
\hline No. & \multicolumn{1}{c}{ Nama } & Jabatan & Pendidikan & $\begin{array}{c}\text { Jenis } \\
\text { kelamin }\end{array}$ \\
\hline 1. & Maulidil Jannah, S.Pd.I & Kepala & S1 & Perempuan \\
\hline 2. & Saoda, S.Pd.I. & Guru kel. B & S1 & Perempuan \\
\hline 3. & Susanti Desianti, S.Pd. & Guru kel. B & S1 & Perempuan \\
\hline 4. & Risdiyatun, S.Pd.I. & Guru kel. A & S1 & Perempuan \\
\hline 5. & Minayanti & Guru kel. A & SMA & Perempuan \\
\hline 6. & Kholifatuz Zahro, S.Pd. & Tenaga Administrasi & S1 & Perempuan \\
\hline
\end{tabular}

\section{Permasalahan}

Adapun permasalahan yang dihadapi oleh RA. Munawarus Sholeh dalam hal pengajaran Bahasa Inggris untuk anak usia dini sebagai berikut:

a. Kurangnya guru yang berkompeten dalam bidang pengajaran bahasa Inggris untuk anak usia dini.

b. Para guru tidak memiliki pengetahuan tentang cara melafalkan kosa kata yang benar.

c. Belum adanya kegiatan pelatihan peningkatan kualitas guru PAUD dalam hal pengajaran Bahasa Inggris untuk anak usia dini $(E Y L)$.

d. Para guru belum mengetahui cara membaca tulisan fonetik yang terdapat di kamus.

e. Tingkat motivasi guru yang berbeda dalam belajar bahasa Inggris

f. Belum adanya pendampingan penyelesaian masalah dalam pengajaran bahasa Inggris 


\section{Target}

Target program pengabdian kepada masyarakat bagi Guru PAUD di Kecamatan Asembagus ini yaitu:

a. Penguasaan kosa-kata dasar bahasa Inggris.

b. Keterampilan melafalkan kosa kata dalam bahasa Inggris.

c. Keterampilan mengajarkan bahasa Inggris kepada anak usia dini.

d. Keterampilan mengetahui pengucapan kata-kata Bahasa Inggris.

e. Motivasi guru PAUD untuk terus mengembangkan keterampilan bahasa Inggrisnya.

f. Pendampingan kepada para guru PAUD dalam menjalankan kegiatan pengajaran Bahasa Inggris untuk menyelesaikan masalah-masalah yang dihadapi.

\section{Luaran}

Luaran yang dicapai melalui kegiatan PKM ini adalah terbentuknya guru PAUD yang berkompeten dalam pengajaran Bahasa Inggris untuk anak usia dini di Kecamatan Asembagus yang dapat diuraikan sebagai berikut:

a. Guru PAUD menguasai beberapa kosa kata dasar Bahasa Inggris yang biasa diajarkan pada anak didik.

b. Guru PAUD dapat melafalkan beberapa kosa kata dasar dalam bahasa Inggris dengan benar.

c. Guru PAUD terampil mengajarkan bahasa Inggris kepada anak usia dini.

d. Guru PAUD mengetahui penggunaan aplikasi kamus dalam mengecek pengucapan kata-kata Bahasa Inggris.

e. Motivasi guru PAUD dalam mengembangkan keterampilan bahasa Inggris meningkat.

\section{METODE PELAKSANAAN}

Dalam melaksanakan kegiatan pengabdian peningkatan kualitas pengucapan kosa kata Bahasa Inggris bagi guru PAUD di Kecamatan Asembagus ini diterapkan empat tahap kegiatan, yaitu persiapan, pelatihan, dan evaluasi.

\section{Tahap Persiapan}

Tahap persiapan di sini meliputi beberapa hal yaitu: observasi, musyawarah, dan kuesioner (pre-test). Tahap observasi dilakukan untuk melihat kembali permasalahan yang dihadapi oleh sekolah mitra. Hal ini bertujuan untuk memastikan kecocokan metode yang akan diterapkan selama masa pengabdian. Dalam masa observasi, pelaksana mencatat hal-hal yang belum teridentifikasi sebelumnya.

Musyawarah dilakukan bersama para guru PAUD untuk mensosialisasikan kegiatan yang dilakukan. Kegiatan ini juga sebagai bentuk penawaran dan permohonan persetujuan para guru PAUD atas kegiatan-kegiatan yang akan dilaksanakan. Selain itu, dibicarakan juga tentang waktu pelaksanaan tahap pelatihan yang disesuaikan dengan waktu senggang para guru. Kegiatan musyawarah ini dimaksudkan agar pada masa pengabdian, para guru PAUD antusias dalam mengikuti kegiatan dan tidak terjadi kesalahpahaman tentang kegiatan pengabdian ini. Dari hasil musyawarah didapatkan kesepakatan bahwa pelatihan dilaksanakan selama empat hari, yaitu pada Selasa, 14 Mei 2019 sampai Jumat, 17 Mei 2019.

Beberapa pertanyaan yang harus dijawab melalui lembar kuesioner diberikan kepada peserta pelatihan pada hari pertama, sebelum pelatihan dimulai. Hal ini untuk mengetahui kemampuan awal yang dimiliki oleh para peserta. Dari isian diketahui bahwa beberapa peserta telah mengetahui metode dan media pembelajaran Bahasa Inggris untuk anak usia dini, namun belum mahir dalam pengucapan kosa kata (pronunciation) serta pemanfaatan teknologi untuk membantu proses belajar mengajar dan pengecekan pelafalan kosa kata dalam Bahasa Inggris.

\section{Tahap Pelatihan}

Pelatihan yang dilaksanakan pada Program Kemitraan Masyarakat ini yaitu Pelatihan Pembelajaran Bahasa Inggris untuk Anak Usia Dini (English for Young Learners). Pelatihan ini dilaksanakan selama empat kali pertemuan dan diikuti oleh seluruh guru RA. Munawawrus Sholeh Mojosari Asembagus serta beberapa guru RA yang terdapat di Kecamatan Asembagus. Pelatihan ini dilaksanakan dengan durasi 90 menit per pertemuannya. 
Tujuan kegiatan ini adalah membekali para guru PAUD dengan beberapa kosa kata Bahasa Inggris dasar, melatih pelafalan kosa kata Bahasa Inggris, memberikan motivasi para guru PAUD untuk belajar Bahasa Inggris, menyampaikan pentingnya belajar Bahasa Inggris bagi anak usia dini $(E Y L)$, serta memberikan metode atau cara belajar mengembangkan kemampuan Bahasa Inggris secara mandiri. Pelatihan ini mencakup beberapa kegiatan yaitu ceramah, kegiatan diskusi, dan simulasi mengajar (micro teaching).

Adapun materi-materi yang disampaikan pada kegiatan pelatihan guru PAUD ini berupa materi yang dapat mendukung kegiatan pengajaran Bahasa Inggris untuk anak usia dini seperti pemberian kosa kata (vocabulary), pelafalan kosa kata Bahasa Inggris (pronounciation), metode pembelajaran, media pembelajaran, pemanfaatan teknologi, motivasi belajar Bahasa Inggris, dan belajar secara mandiri (autonomous learning).

Pada setiap sesi, diberikan kosa kata dasar yang akan mendukung pengajaran Bahasa Inggris untuk anak usia dini. Kosa kata dasar yang diberikan merupakan kosa kata yang berkaitan dengan tema yang diajarkan di sekolah mitra. Pemilihan tema ini disesuaikan dengan permintaan para guru saat musyawarah sebelum pelatihan dilaksanakan. Adapun tema kosa kata dasar yang diberikan pada saat pelatihan yaitu: parts of body (bagian tubuh) dan family members (anggota keluarga), colours (warna), alphabet and numbers (huruf dan angka).

Pada bagian pronounciation, peserta pelatihan dilatih cara melafalkan beberapa kosa kata dasar yang telah diberikan. Menurut Ashmore (2012), ada beberapa kegiatan yang dapat dilakukan untuk melatih pronounciation anak usia dini, yaitu lagu (songs), mendengarkan cerita (listening to stories), permainan (games), tongue twisters.

Berdasarkan uraian tersebut, disebutkan bahwa pemberian kosa kata dan pelatihan pengucapan melalui lagu (songs) merupakan cara yang paling efektif diterapkan pada pembelajaran Bahasa Inggris untuk anak usia dini. Sebuah penelitian yang dilakukan oleh Khairani (2016) menyimpulkan bahwa lagu nyanyian merupakan metode yang sangat sesuai dan berhasil dalam pendidikan Bahasa Inggris untuk anak usia dini. Hal ini juga didukung oleh Sophya (2013, hal. 1) yang mengatakan bahwa lagu merupakan media yang bagus untuk meningkatkan kemampuan Bahasa Inggris anak usia dini. Maka pada saat pelatihan, diberikan beberapa lagu yang sesuai dengan tema materi pelatihan. Selain melalui lagu, latihan pelafalan juga dilakukan melalui praktek langsung melafalkan kata. Praktek langsung ini diterapkan kepada setiap peserta. Hal ini sangat efektif dilakukan karena didukung oleh jumlah peserta yang tidak terlalu banyak.

Hal yang paling dibutuhkan oleh anak usia dini dalam hal belajar bahasa adalah bagaimana mengucapkan sebuah kata. Maka metode pembelajaran yang paling cocok untuk pengajaran Bahasa Inggris pada anak usia dini yaitu dengan metode fonik. Fonik merupakan sebuah metode dalam membaca dan pengejaan dalam bahasa Inggris dengan memberikan kesadaran akan hubungan antara bunyi dan pengejaan (English First, 2016). Dengan menggunakan metode ini, maka anak didik akan dengan cepat mengingat beberapa kosa kata dalam Bahasa Inggris.

Metode lain yang dapat diterapkan untuk pembelajaran Bahasa Inggris untuk anak usia dini yaitu dengan menggunakan permainan tradisional. Aprilyanti (2015) berdasarkan penelitian yang dilakukannya mengatakan bahwa penerapan permainan tradisional berpengaruh terhadap perkembangan kemampuan Bahasa Inggris anak usia dini. Namun pada pelatihan ini, metode pembelajaran Bahasa Inggris melalui permainan tradisional ini tidak diberikan dikarenakan waktu pelatihan yang tidak memungkinkan.

Pada materi media pembelajaran, peserta diajarkan untuk menggunakan media yang sesuai dengan pembelajaran Bahasa Inggris untuk anak usia dini. Mengajar Bahasa Inggris pada anak usia dini harus menggunakan metode yang membuat mereka terhibur (Sophya, 2014). Selanjutnya Sophya (2014, hal. 263) mengatakan ada 3 kelompok media pembelajaran yang dapat digunakan untuk mengajar anak usia dini, yaitu: 1) media visual, yaitu media yang mengantarkan pesan melalui penglihatan anak. Contohnya, 
gambar diam, media grafis, media model, dan media realita. 2) media audio, yaitu media yang mengandung pesan dalam bentuk auditif, hanya dapat didengar. Contohnya, kaset suara dan radio. 3) media audiovisual, Media ini dapat menyajikan isi tema secara utuh kepada anak didik. Contohnya, televisi, video pendidikan, dan sebagainya.

Pada materi pemanfaatan teknologi disampaikan beberapa manfaat dari kemajuan teknologi untuk diterapkan dalam pembelajaran Bahasa Inggris untuk anak usia dini. Pemanfaatan teknologi melalui telepon genggam sangat efektif untuk mencari bahan ajar berupa video dan gambar. Selain itu, teknologi juga sangat membantu dalam meningkatkan kemampuan para guru dalam pelafalan kosa kata melalui pengecekan pelafalan pada aplikasi kamus yang dapat diunduh dan digunakan kapanpun dan di manapun para guru membutuhkannya. Pada sesi ini, peserta pelatihan utamanya dilatih tentang bagaimana cara menginstal aplikasi kamus dan menggunakan kamus tersebut untuk mengetahui kosa kata dan sekaligus mengecek pelafalan katanya. Materi ini penting melihat keluhan para guru PAUD mengenai kelemahan mereka dalam melafalkan kosa kata Bahasa Inggris.

Materi berikutnya yaitu motivasi. Motivasi adalah kekuatan-kekuatan dari dalam individu yang menggerakkan individu untuk berbuat. Motivasi belajar merupakan kekuatan mental yang mendorong terjadinya proses belajar. Motivasi dapat menentukan baik tidaknya dalam mencapai tujuan, sehingga semakin besar motivasinya akan semakin besar kesuksesan belajarnya (Purnamasari 2015, hal. 16). Motivasi untuk terus mengembangkan kemampuan Bahasa Inggris ini penting diberikan pada peserta pelatihan yang merupakan guru PAUD karena guru PAUD merupakan tonggak awal kemampuan yang dimiliki oleh anak didik. Jika pengetahuan yang diberikan keliru, maka ke depannya anak didik akan memiliki pengetahuan yang keliru.

Materi Autonomous Learning sangat penting agar guru tetap mengembangkan kemampuan Bahasa Inggrisnya untuk disampaikan kepada anak didik. Dalam materi ini peserta pelatihan diajarkan bagaimana belajar Bahasa Inggris secara mandiri, metode dan media apa saja yang dapat digunakan untuk belajar. Selain itu dikenalkan pula kamus elektronik dan media lain yang bisa dimanfaatkan melalui smartphone dan teknologi lainnya. Dengan pemberian materi ini, diharapkan guru dapat terus mengembangkan kemampuannya meskipun tanpa bimbingan dari orang lain, khususnya pada saat berakhirnya masa pengabdian.

\section{Tahap Evaluasi}

Tahap evaluasi dilakukan pada akhir masa pelatihan, yaitu melalui sesi micro teaching dan post test. Evaluasi dilakukan oleh pelaksana kegiatan terhadap kualitas pengajaran Bahasa Inggris para guru serta oleh peserta pelatihan terhadap kinerja pelaksana kegiatan. Beberapa masukan diberikan berdasarkan hasil yang dapat dilihat pada saat micro teaching. Evaluasi ini diharapkan menjadi masukan bagi para guru agar setiap waktu dapat menunjukkan kualitas pengajaran Bahasa Inggris yang semakin baik. Evaluasi juga diadakan untuk melihat keefektifan pelaksanaan pelatihan pembelajaran Bahasa Inggris untuk anak usia dini (English for Young Learners) ini, yaitu melalui isian kuesioner posttest. Diharapkan evaluasi ini akan memberi masukan utamanya bagi pelaksana kegiatan agar dapat meningkatkan kualitas program pada masa yang akan datang.

\section{HASIL DAN PEMBAHASAN}

Dari hasil musyawarah bersama kepala sekolah RA. Munawarus Sholeh, maka dihasilkan kesepakatan bahwa pelatihan Pengajaran Bahasa Inggris untuk Anak Usia Dini (English for Young Learners) dilaksanakan sebanyak empat kali pertemuan, yaitu pada tanggal 14 - 17 Mei 2019 . Adapun jadwal pelaksanaannya seperti ditunjukkan dalam tabel berikut: 
Tabel 3. Jadwal Kegiatan Pelatihan

\begin{tabular}{cl}
\hline \multicolumn{1}{c}{ Hari/Tanggal } & \multicolumn{1}{c}{ Materi } \\
\hline Selasa, 14 Mei 2019 & Perkenalan \\
\cline { 2 - 2 } & Pre-test \\
\cline { 2 - 2 } & $\begin{array}{l}\text { Anggota tubuh (Parts of Body) } \\
\text { Anggota keluarga (Family Members) }\end{array}$ \\
\hline Rabu, 15 Mei 2019 & Warna (Colours) \\
\hline Kamis, 16 Mei 2019 & Huruf (Alphabet) \\
& Angka (Numbers) \\
\hline Jumat, 17 Mei 2019 & Pemanfaatan Teknologi \\
\cline { 2 - 2 } & Microteaching \\
\cline { 2 - 2 } & Post-test \\
\hline
\end{tabular}

\section{Hari Pertama}

Hari pertama dilaksanakan pada Selasa, 14 Mei 2019. Peserta pelatihan yang hadir yaitu sebanyak 12 orang peserta, terdiri atas guru RA Munawarus Sholeh dan beberapa guru RA di Kecamatan Asembagus. Pada hari pertama ini dilaksanakan tiga sesi, yaitu perkenalan, pre-test, dan materi 1 (Parts of Body \& Family Members).

Sesi pertama, perkenalan disampaikan oleh ketua pelaksana, yaitu Firqo Amelia. Pada sesi perkenalan ini, pelaksana kegiatan menyampaikan maksud dan tujuan dilaksanakannya Program Kemitraan Masyarakat ini. selain itu, pelaksana juga menyampaikan materi apa saja yang akan diberikan pada pelatihan tersebut serta apa saja yang akan didapatkan oleh peserta pelatihan. Kemudian, profil singkat para pelaksana kegiatan juga disampaikan pada sesi tersebut.

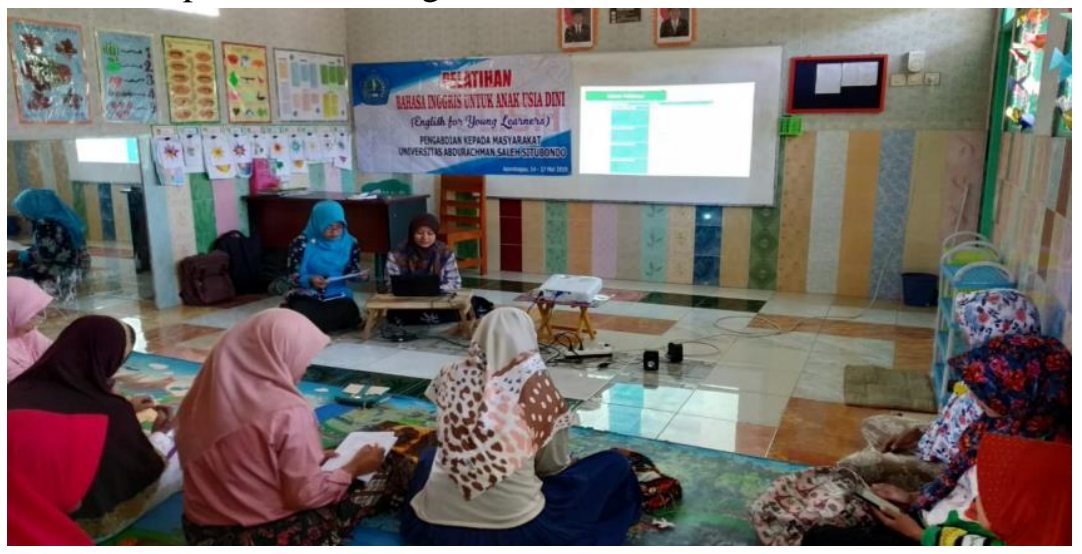

Gambar 2. Perkenalan program dan pelaksana pengabdian

Kegiatan kedua yaitu pre-test. Pada sesi ini diketahui bahwa mayoritas peserta pelatihan belum memahami bagaimana cara pelafalan kosa kata dalam Bahasa Inggris serta belum mengetahui bagaimana cara mengetahui pelafalan kosa kata dalam Bahasa Inggris tersebut.

Kegiatan dilanjutkan dengan pemberian materi pertama dengan tema anggota badan (parts of body) dan anggota keluarga (family members) oleh Sufil Lailiyah. Para peserta terlihat sangat antusias dalam mengikuti sesi ini. Pemateri juga memberikan lagu tentang anggota badan yang dapat diterapkan pada proses pembelajaran Bahasa Inggris di kelas. Lagu ini sangat efektif untuk memperkenalkan kosa kata tentang anggota tubuh karena disertai dengan gerakan menunjuk anggota tubuh yang disebutkan. Lagu ini juga sangat mudah untuk dihafal oleh para peserta karena ritmenya menggunakan ritme yang biasa digunakan pada lagu anak yaitu lagu "Kepala pundak lutut kaki". Adapun teks lagunya sebagai berikut:

\section{Parts of Body}

Head, shoulders, knees, and feet. Knees and feet. Head, shoulders, knees, and feet. Knees and feet. And eyes, and ears, and mouth, and nose Head, shoulders, knees, and feet. Knees and feet. 


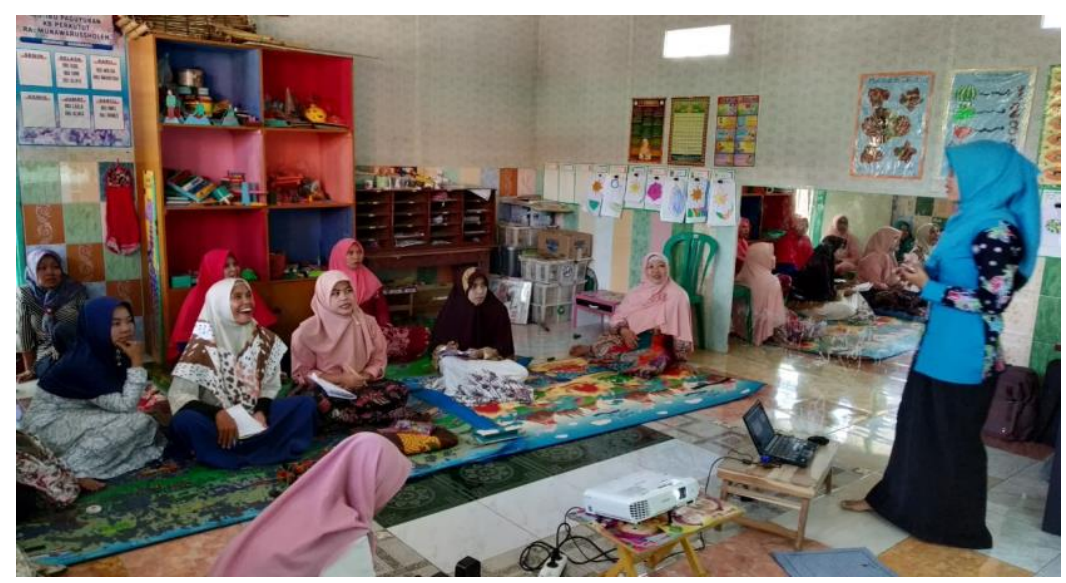

Gambar 3. Pemberian materi Parts of body dan Family members

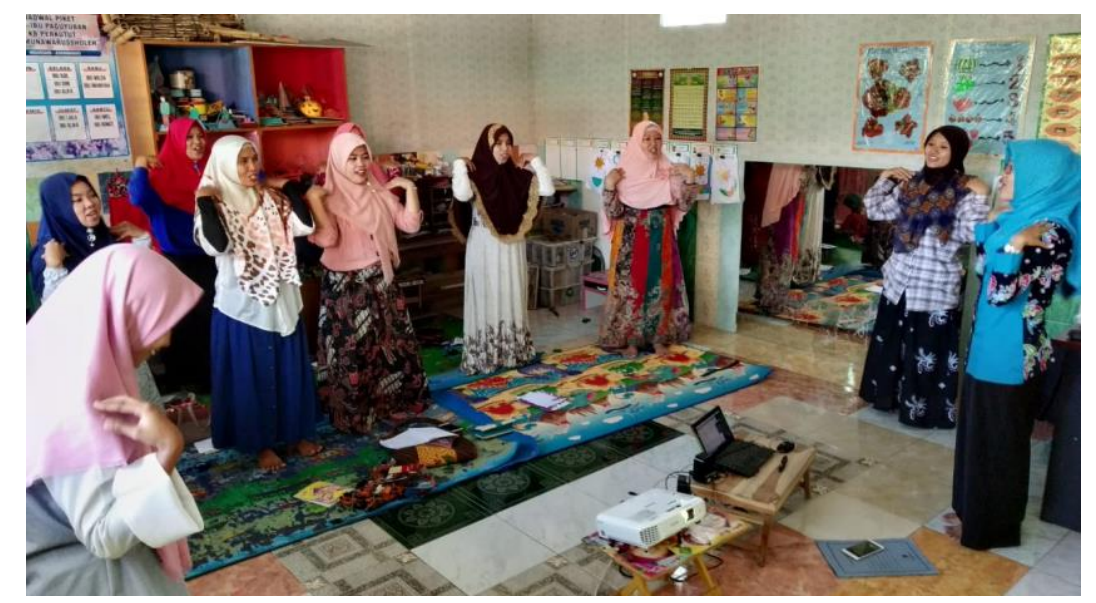

Gambar 4. Praktek menyanyikan lagu Parts of Body

\section{Hari Kedua}

Hari kedua dilaksanakan pada Rabu, 15 Mei 2019. Pelaksanaan pelatihan hari kedua ini diikuti oleh sepuluh orang peserta. Hanya ada satu sesi pada hari tersebut, yaitu pemberian kosa kata dan metode pembelajaran bertema warna (colours) yang disampaikan oleh Izzah Afkarina. Dalam sesi ini, Izzah memberikan lagu berjudul
"There are many colours". Lagu ini juga mudah dihafal karena ritmenya menyadur ritme lagu yang sudah terkenal, yaitu "Twinkle-twinkle". Adapun teks lagunya sebagai berikut:

Adapun untuk menarik perhatian anak didik, lagu ini dinyanyikan dengan menunjuk benda-benda berwarna sesuai dengan warna yang disebutkan pada saat bernyanyi

$\begin{aligned} & \text { Colours } \\ & \text { Merah }=\text { red } \\ & \text { Biru }=\text { blue } \\ & \text { Kuning }=\text { yellow } \\ & \text { Hijau }=\text { green } \\ & \text { Ungu }=\text { purple } \\ & \text { Hitam }=\text { black } \\ & \text { Jingga }=\text { orange } \\ & \text { Putih }=\text { white } \\ & \text { Ada banyak warna }=\text { There are many colours }\end{aligned}$




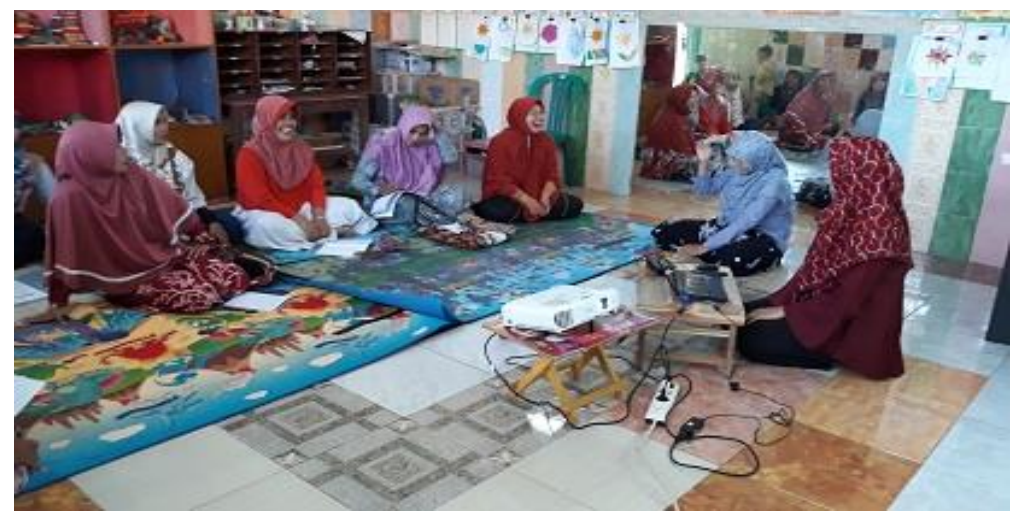

Gambar 5. Pemberian materi Colours

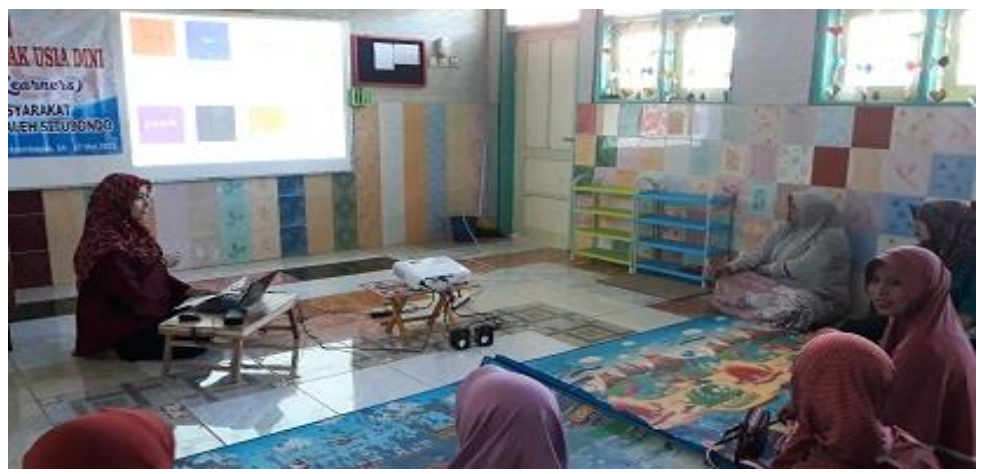

Gambar 6. Praktek menyanyikan lagu There are many colours

\section{Hari Ketiga}

Hari ketiga dilaksanakan pada Kamis, 16 Mei 2019. Hari ketiga ini diikuti oleh delapan orang peserta. Pada sesi ini materi yang disampaikan adalah kosa kata tentang huruf dan angka (alphabet and numbers). Materi ini disampaikan oleh Lailatul Hasanah. Sama halnya dengan materi kosa kata sebelumnya, pemateri mengecek pelafalan huruf masing-masing peserta kemudian membahas bersama-sama kebenaran dan kekeliruan pelafalan yang diucapkan oleh peserta. Setelah sesi pengecekan, pemateri memberikan lagu yang cukup familiar, namun ada tambahan frase di akhir lagunya. Adapun teks lagunya adalah sebagai berikut:

Alphabet

$A, B, C, D, E, F, G$

$H, I, J, K, L, M, N$

$O, P, Q, R, S, T, U$

$V, W, X, Y, Z$

Now I know my $A B C$

Twenty-six letters from $A$ to $Z$

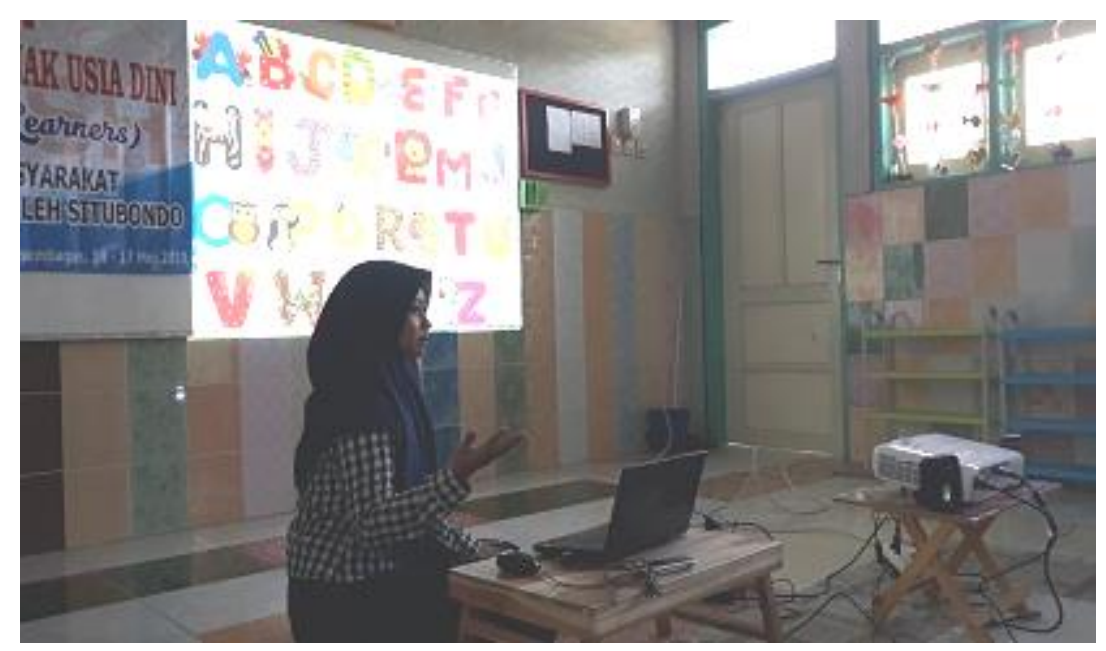

Gambar 7. Pemberian materi Alphabet dan Numbers 


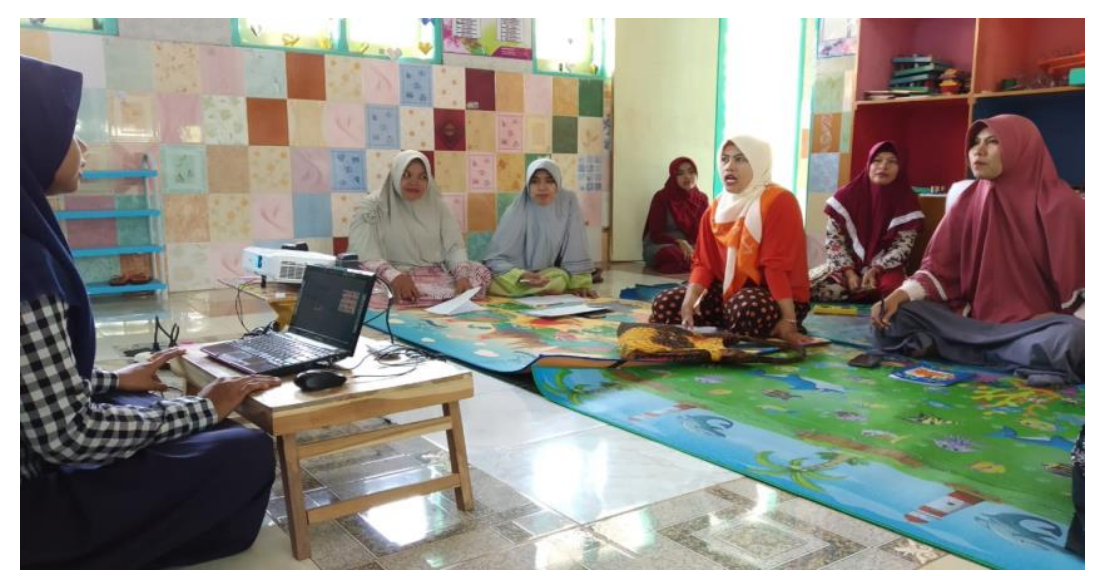

Gambar 8. Praktek menyanyikan lagu Alphabet

\section{Hari Keempat}

Hari keempat dilaksanakan pada Jumat,

17 Mei 2019 dan dihadiri oleh delapan orang peserta. Terdapat tiga agenda pada pelaksanaan pelatihan hari keempat ini, yaitu materi Pemanfaatan Teknologi, praktek mengajar (micro teaching), dan post-test.

Materi Pemanfaatan Teknologi disampaikan oleh Firqo Amelia. Pada materi ini, peserta diperkenalkan pada manfaat-manfaat teknologi, utamanya untuk mendukung peningkatan kualitas pembelajaran Bahasa Inggris untuk anak usia dini, yaitu sebagai media pembelajaran dengan video dan gambar yang dapat dicari di internet. Kemudian juga metodemetode terbaru yang dapat diakses melalui peralatan canggih seperti komputer dan telepon genggam. Selain itu, pada materi ini juga diperkenalkan aplikasi kamus yang dapat digunakan secara luring (offline) yang berguna untuk mengetahui kosa kata dalam Bahasa Inggris sekaligus mengecek pelafalan kosa kata tersebut. Pada saat materi tersebut, peserta diajak untuk langsung mempraktekkan dengan mengunduh dan meng-install aplikasi kamus pada telepon genggam para peserta, kemudian mempraktekkan mencari arti kata serta pelafalan dalam kamus tersebut. Dua aplikasi kamus yang diperkenalkan dan direkomendasikan untuk digunakan adalah aplikasi "Kamusku" untuk kamus Inggris-Indonesia \& Indonesia-Inggris serta "Merriam Webster Dictionary" untuk kamus Inggris-Inggris.
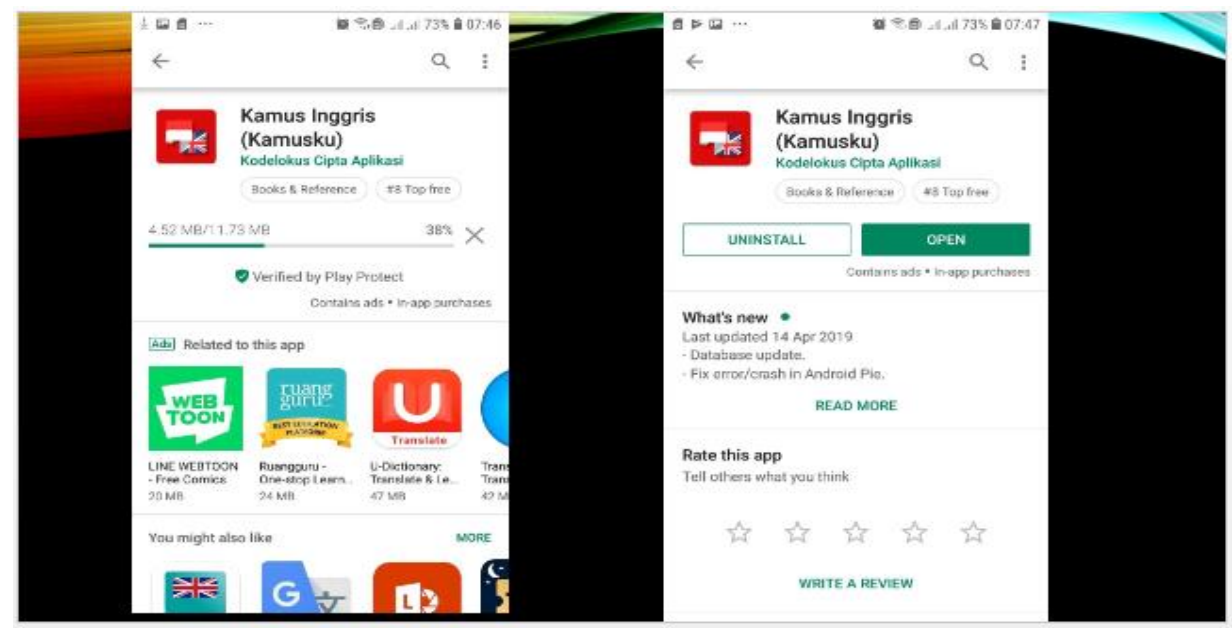

Gambar 8. Aplikasi kamus "Kamusku" 


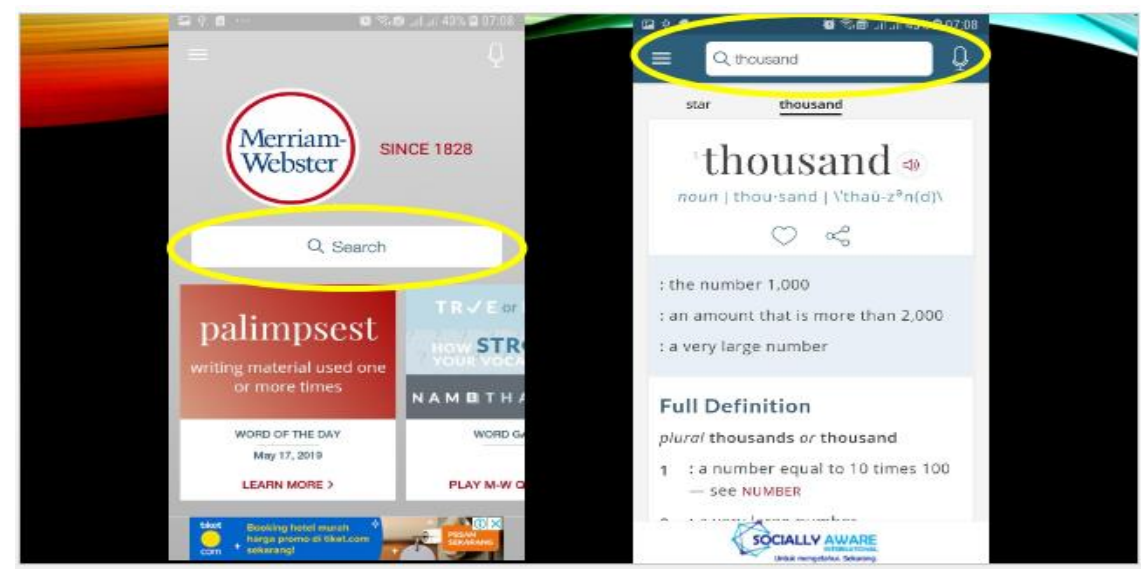

Gambar 9. Aplikasi kamus "Merriam-Webster Dictionary"

Sesi selanjutnya yaitu praktek mengajar (micro teaching). Untuk melihat kemampuan pengajar setelah mengikuti pelatihan, dua orang peserta melakukan simulasi mengajar, yaitu Susanti Desianti, S.Pd. dan Saoda, S.Pd.I. Bu Santi mengaplikasikan materi Alphabet, sedangkan $\mathrm{Bu}$ Saoda mengaplikasikan materi Parts of body. Keduanya sangat bagus dalam mempraktekkan cara mengajar Bahasa Inggris untuk anak usia dini. Dari hasil evaluasi, hanya terdapat sedikit kesalahan pelafalan.

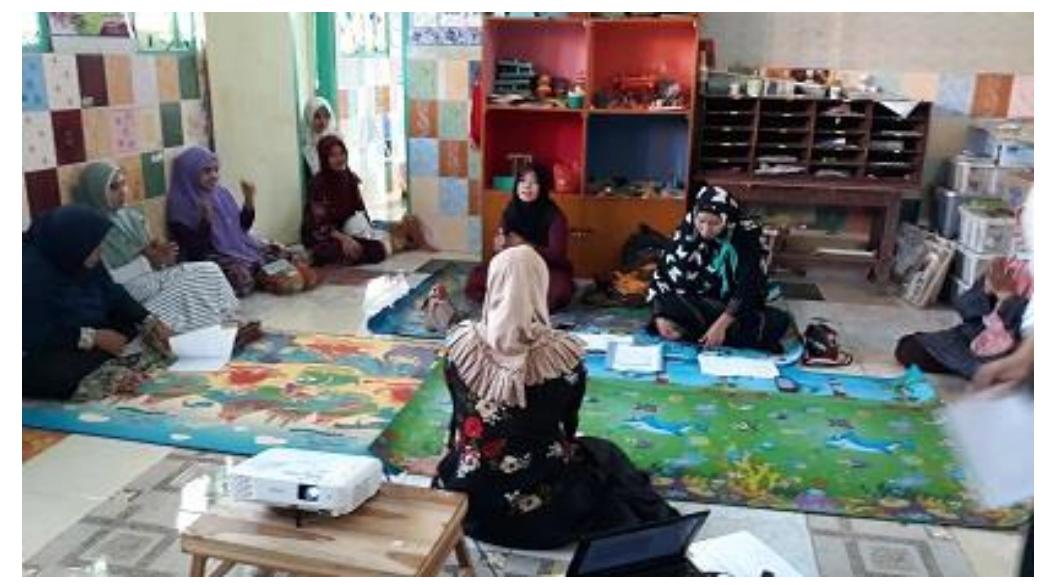

Gambar 10. Praktek mengajar oleh salah satu guru PAUD

Sesi terakhir yaitu post-test. Kuesioner post-test diisi oleh para peserta pelatihan untuk melihat kebermanfaatan diadakannya pelatihan tersebut. Dari hasil isian jawaban peserta dapat disimpulkan bahwa peserta pelatihan mengalami peningkatan kemampuan dalam hal metode pembelajaran EYL, media pembelajaran EYL, cara pelafalan kosa kata Bahasa Inggris, cara mengecek pelafalan, serta pengetahuan tentang aplikasi kamus.

Beberapa luaran yang dihasilkan dari kegiatan Program Kemitraan Masyarakat Pendampingan Peningkatan Kualitas Pengajaran Bahasa Inggris bagi Guru PAUD di Kecamatan Asembagus yaitu: a. Bertambahnya kosa kata dasar Bahasa Inggris Guru RA. PAUD yang biasa diajarkan pada anak didik.

b. Pelafalan beberapa kosa kata dasar Bahasa Inggris guru PAUD yang benar.

c. Keterampilan guru PAUD dalam mengajarkan bahasa Inggris kepada anak usia dini.

d. Keterampilan guru PAUD dalam menggunakan aplikasi kamus dalam mengecek pengucapan kata-kata Bahasa Inggris.

e. Motivasi guru PAUD dalam mengembangkan keterampilan bahasa Inggris yang meningkat. 


\section{SIMPULAN DAN SARAN}

Dari kegiatan pelatihan pengucapan Bahasa Inggris bagi guru PAUD di Kecamatan Asembagus ini dapat disimpulkan beberapa hal yaitu:

1. Mayoritas guru PAUD membutuhkan bantuan dalam hal perbaikan pelafalan kosa kata Bahasa Inggris

2. Metode yang paling efektif untuk diterapkan pada proses pembelajaran Bahasa Inggris untuk anak usia dini yaitu melalui lagu (songs)

3. Aplikasi kamus pada telepon genggam sangat membantu pengecekan pelafalan kosa kata Bahasa Inggris guru PAUD

4. Motivasi guru PAUD untuk meningkatkan kemampuan Bahasa Inggris sangat tergantung pada kebutuhan dalam pembelajaran Bahasa Inggris di kelas

Mengingat guru PAUD merupakan sandaran orang tua untuk pendidikan dasar bagi putera-puterinya, maka terjaminnya kualitas para guru PAUD sangat perlu diperhatikan. Dengan melihat fakta bahwa masih banyak guru PAUD yang keliru dalam melafalkan kosa kata Bahasa Inggris dalam mengajarkannya pada anak didik mereka, maka pelatihan Bahasa Inggris terutama untuk membantu memperbaiki pelafalan kosa kata sangat dibutuhkan. Oleh karenanya penulis menyarankan agar kegiatan pelatihan Bahasa Inggris untuk guru PAUD dapat terus dilaksanakan terutama bagi masyarakat yang memiliki kompetensi di bidang Bahasa Inggris. Harapannya, anak-anak PAUD mendapatkan kosa kata dengan pelafalan yang benar sejak usia dini.

\section{UCAPAN TERIMA KASIH}

Ucapan terima kasih kami sampaikan untuk semua pihak yang terlibat dalam kegiatan ini. Pertama, pihak kampus Universitas Abdurachman Saleh Situbondo melalui Pusat Penelitian dan Pengabdian Masyarakat (P3M) yang telah mengoordinir kegiatan pengabdian ini. Kedua, Dekan Fakultas Sastra yang telah mengizinkan para pelaksana untuk melakukan kegiatan pengabdian ini. Ketiga, Kepala RA Munawarus Sholeh Asembagus yang telah bersedia bekerja sama dan memfasilitasi kami melakukan pengabdian di RA Munawarus Sholeh Mojosari Asembagus. Keempat, guru RA Munawarus Sholeh Asembagus dan beberapa guru PAUD di Kecamatan Asembagus yang telah membantu dan bekerja sama untuk melakukan pengabdian ini. Terakhir, para pelaksana dan tutor yang bersedia meluangkan waktu mempersiapkan acara, memberi materi, dan melakukan evaluasi pada akhir pengabdian. Hanya ucapan terima kasih yang dapat kami sampaikan dan doa semoga mendapat balasan dari Yang Maha Kuasa. Amin.

\section{DAFTAR PUSTAKA}

Aprilyanti, D.S. (2015). Mengembangkan Kemampuan Bahasa Inggris Anak Usia Dini Melalui Permainan Tradisional Modifikatif. Jurnal Pendidikan. Online. http://kd-cibiru.upi.edu/jurnal [diakses pada 7 Juni 2017]

Ashmore, K. (2012). Pronounciation Activities. Online. http://learnenglishkids.British council.org [diakses pada 11 Juni 2017]

English First. (2016). Kunci Belajar Bahasa Inggris Untuk Anak Usia Dini - EF Blog. Retrieved December 19, 2019, from https://www.ef.co.id/englishfirst/efblog/edu cational-advice/tips-orang-tua/kuncibelajar-bahasa-inggris-untuk-anak-usiadini/

Khairani, A. I. (2016). Pendidikan Bahasa Inggris Untuk Anak Usia Dini (Politeknik Negeri Medan). Retrieved from http://digilib.unimed.ac.id/id/eprint/448

Pemerintah Indonesia. Undang-Undang Republik Indonesia Nomor 20 Tahun 2003 tentang Sistem Pendidikan Nasional. , (2003).

Purnamasari, L. (2015). JEPANG TERHADAP HASIL BELAJAR BAHASA JEPANG SKRIPSI Diajukan sebagai salah satu syarat untuk memperoleh gelar Sarjana Pendidikan Prodi Pendidikan Bahasa Jepang oleh Laila Purnamasari Jurusan Bahasa dan Sastra Asing Fakultas Bahasa dan Seni Universitas Neg (Universitas Negeri Semarang). Retrieved from http://lib.unnes.ac.id/21517/1/2302410055s.pdf

Sohnata Hutauruk, B. (2015). Children First 
Language Acquisition At Age 1-3 Years Old In Balata. IOSR Journal Of Humanities And Social Science Chomsky Bolinger, 20(8) 2279-2845.

https://doi.org/10.9790/0837-20855157

Sophya, I. V. (2013). Melalui Lagu Pada Anak Usia Dini. Thufula, 1(1), 1-21.

Sophya, I. V. (2014). Desain Pembelajaran
Bahasa Inggris Untuk Pendidikan Anak Usia Dini. ThufuLA: Jurnal Inovasi Pendidikan Guru Raudhatul Athfal, 2(2), 251-268.

https://doi.org/10.21043/thufula.v2i2.4639

UNICEF Indonesia. Oktober (2012). Ringkasan Kajian. Online. https://www.unicef.org/ indonesia/id [diakses pada 27 April 2017] 